\title{
AUTOMATION OF THE TECHNOLOGICAL FLOW IN CASIAL CEMENT FACTORY
}

\author{
S. Arad, V. Arad, and V. Cosma
}

\begin{abstract}
Cement production is an energy intensive process that consumes a significant portion of world energy. Significant optimization of the traditional cement grinding process can be achieved. Control system, automation and monitoring software assure means of improving the efficiency of the technological flow and of optimizing the energy consumption in Casial Cement Plant.
\end{abstract}

Index Terms - Automation, Microprocessor applications, Process control, Programmable logic devices.

\section{INTRODUCTION}

$\mathrm{T}$ HE Casial Cement Plant is located in Chiscadaga village, next to Deva town, $400 \mathrm{~km}$ northwest of Bucharest. The Plant was founded in 1972 and begun to work in 1976. In 2000, HeidelbergCement acquired a majority stake in the cement plant Casial Deva. In April 2000, the cement plant Casial Deva, becomes one of the three members of the Heidelberg Cement Group, being one of the most significant cement producers in western Romania. In October 2002, Heidelberg Cement became the majority shareholder in the company

Carpatcement Romania is the Heidelberg Cement company that coordinates the activity over the Romanian cement market and assists the factories which are members of the Group in financial and investment management, as well as in modernization.

The Casial Deva Company has got two technological lines to produce cement with 1,9 millions tons a year capacity. The basic product is cement, $80 \%$ is clinker manufactured using a dry procedure which allows a production of 4,000 tones of clinker a year.

The flowsheet of material balance is presented in figure 1 .

As a company policy, Casial Deva achieved a significant technology modernization program begin in 1998 year. The modernizations were made in two stages and aimed technological performance improvement and environment protection.

S. Arad is associate professor to the Electrotechnical Department of Petrosani University, Petrosani, Romania, (e-mail: arad@ dec.com.ro; s_arad@upet.ro).

V.Arad. is professor to the Rock Mechanic Department of Petrosani University, Petrosani Romania (e-mail: varad@upet.ro).

V. Cosma is student to The "Polytechnica" University of Timisoara, Romania (e-mail: rockdajam@yahoo.com).
The technological process efficiency increment aims mainly the following indicators:

- Energy specific consumption reducing

- Fuel and electric energy consumption diminishing

- Raw material consumption decreasing

- Respecting the legal quality of soil, air and water

\section{ENERGETIC ASPECTS IN CEMENT MANUFACTURING AT CASIAL DEVA}

The current world consumption of cement is about 1.7 billion tones per annum and it is increasing at about $1 \%$ per annum.

Manufacturing cement by dry procedure is a huge energy consuming process. A cement kiln - the world's largest manufacturing machine - is the major component of the cement line. The kiln is a large rotating furnace approximately $100 \mathrm{~m}$ long, and four to seven $\mathrm{m}$ in diameter that weighs over 300 tones, figure 2 .

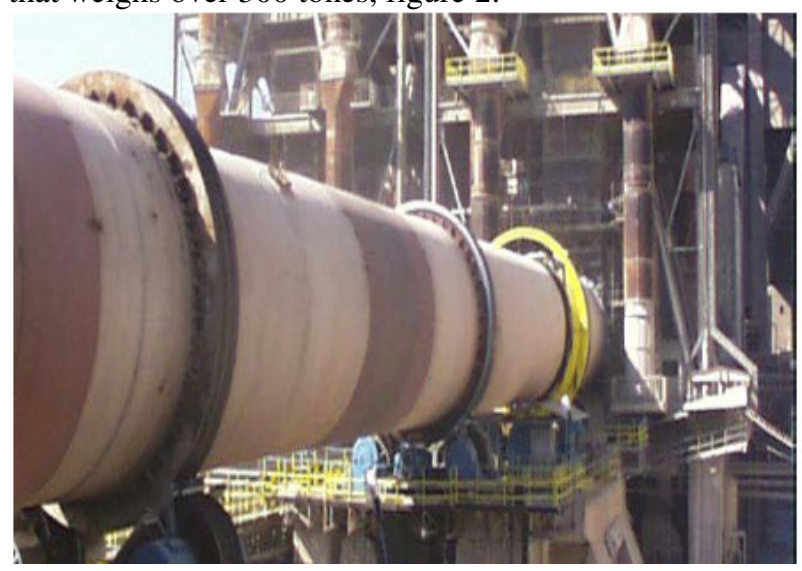

Figure 2.The cement kiln in Casial cement Plant

It heats raw materials, such as limestone, clay and shale, at temperatures over 2700 degrees $\mathrm{F}$ to produce clinker, which is then ground together with gypsum to form cement.

Approximately one tone of cement is produced from 1,5 tones of raw materials. Production costs and environmental concerns are emphasizing the need to use less energy and therefore the development of more energy efficient machines for grinding and classification.

The electrical energy consumed in the cement making process is approx. $110 \mathrm{kWh} /$ tone, $5 \%$ is used in the excavation, crushing and homogenization of raw material, 38 $\% \mathrm{kWh} / \mathrm{t}$ is the energy consumption for clinker grinding, $22 \%$ 
for heating and cooking, $24 \%$ for farine grinding and the rest for other operations (Figure 3).

In 2000, in the Casial Deva Company, $40 \%$ of the total energy (59.813 MWh) was used by the cement mills, $27 \%$ was used by the farine mills and $27 \%$ by the kilns.

For this reason, the Company decided to modernize the process with a goal of increasing production and reducing energy. Requirements included controlling the speed of the kiln, smooth starting and stopping, quick re-start capability, and high availability of the control system.

The solution proposed is implemented medium voltage drive technology an isolation transformer and a Programmable Logic Controller (PLC) to coordinate the system.

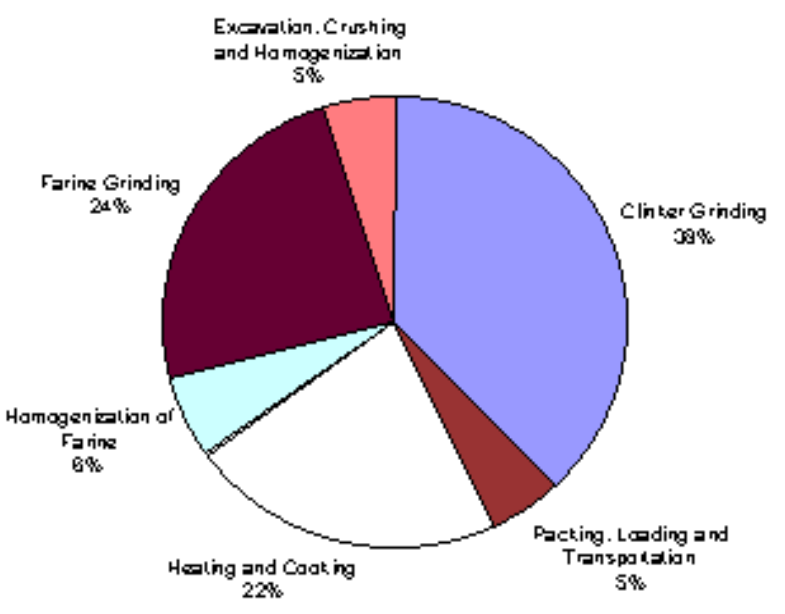

Figure 3.Percentage of energy consumption in each stage of cement process

Electrical energy, fuel and raw material consumption decreasing was obtained as a result of the technology modernization. Compared to 1998 year, the electrical energy specific consumption decreased from, $148 \mathrm{kWh} /$ tone to 129 $\mathrm{kWh} /$ tone in 2001 year.

\section{AUTOMATION MEANS IN TECHNOLOGICAL FLOW AT CASIAL PLANT}

In 1998 year, begun the modernization one of the technological lines, which have 3.7 tone/day capacity. The first stage ended in 2000 and aimed the modernization of the cooler grate in a view to reduce the cooling air flow as well as the electric energy consumption with $2,31 \mathrm{kWh} /$ tone, to increase the clinker manufacturing efficiency from 3000 tone/day to 4000 tone/day and proportional decreasing of the powder and polluting gases.

In this stage, the company aimed:

- The modernization and automation of the heat exchanger and of the farine preparing kiln;

- The modernization of the cement mill no. 3 through the automat dosage and raw materials grinding;

- The modernization of the transport system;

- The assembly of an automate rotary sacking installation;

- The modernization of the gas conditioning tower at the clinker kiln no. 2 ;

- Implemented of automation control system;

Besides the technological flow modernization measures, the company adopted certain solutions for improving the performances linked to the technological process automation and optimal control. A local control in each particular operation and an optimum control of entire plant are enforced. The technological flow on-line simulation and control through specific software in order to get optimal process parameters represent possibilities of improving the performances.

Simplified structure of a control system is presented in figure 4 .

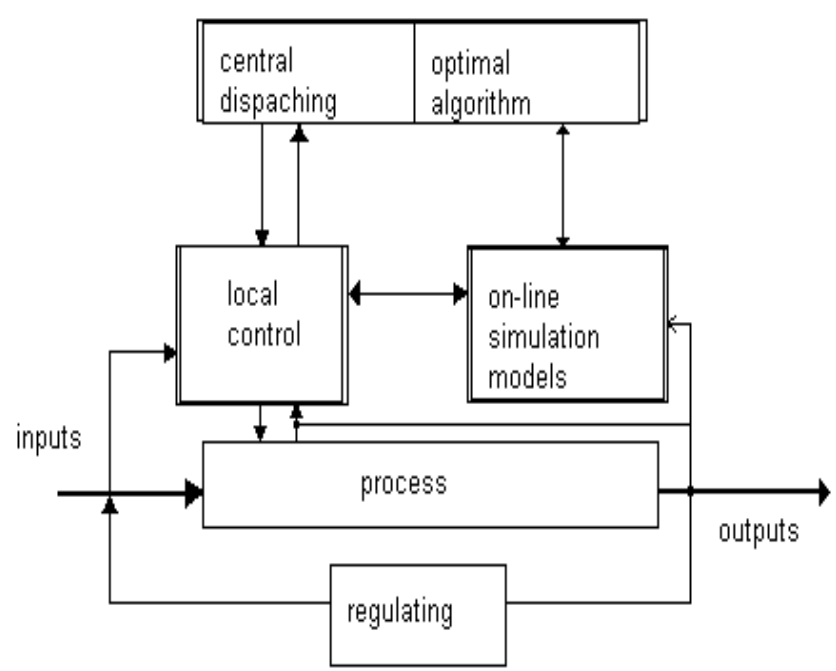

Figure 4. Simplified structure of a control system

From this point of view, the installation was equipped with measuring and control devices, transducers, programmable automate. Local process automation, dispatching and monitoring were accomplished. The automate control is achieved by modern hardware and software.

The technological flow control in the cement factory is presented in figure 5 .

Computer systems can perform both simple logic control of hardwired systems and also be programmed to make decisions between alternatives taking into account a wider range of circumstances. The value of the decision made will depend on the validity of the data used and of logic programmed into the computer.

Microprocessor-based technology allowed developing and implementing new sophisticated measuring systems. It was also possible, due to computer control systems, to introduce more complex control strategies such as: process modelling, predictive control, adaptive control, optimisation control, fuzzy control, etc 


\section{CONCLUSIONS}

The automation can help cement producers meet the challenges of intensifying global competition, high production costs and increasingly stringent environmental standards.

We are using a control system with software monitoring and we can find an optimal solution that:

- increases production rates for everything, from primary crushing to final milling by integrating our information, automation and power systems into a total site solution;

- reduces energy costs through advanced regulatory control that optimizes the energy used in milling and burning processes with the material flow rate;

- increases uptime through power and automation components that feature built-in device level diagnostics and communications;

- improves product quality while complying to environmental regulations through on stream process analysis and emission monitoring.

We can capture, analyze, store, and share energy data across an entire enterprise via a LAN or WAN using a simple web browser. This makes it a snap to distribute the needed knowledge to optimize energy consumption, which can help improving productivity while lowering energy costs.

\section{REFERENCES}

[1] S. (Vlad) Arad, "Evaluarea impactului poluanților evacuați în atmosferă la SC Casial SA Deva”, M.S.thesis, University of Petroşani, Romania, 2001

[2] S. Arad, L.Samoila, D. Visalon, "Energetic considerations in cement manufacture at CASIAL Deva, Cement Factor", International Conference on Applied and Theoretical Electricity, Craiova, Romania, 2004

[3] L. Dobrescu, "Tehnologia industriilor extractivă şi energetică”, Didactic and Pedagogic Publishing House, Bucharest, 1980

[4] Jankovic, "Cement millimg simulations" Journal of Mining and Matallurgy, Technical Faculty and Copper Institute, Bor, Serbia and Montenegro, vol. 39 no.(1-4), 2003, pp.11-23

[5] S.C. Casial, Deva, "Program pentru conformare", Deva, 2000

[6] www.heidelbergcement

[7] www.software.rockwell.com

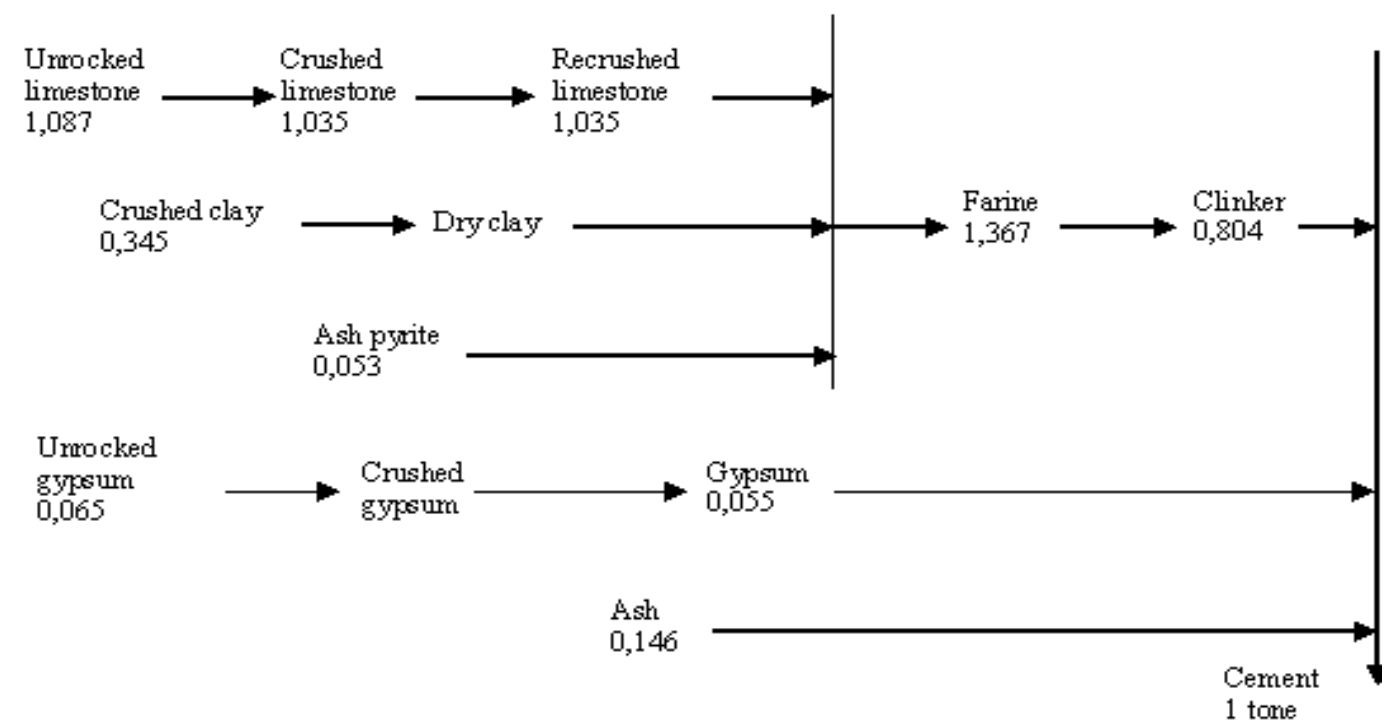

Figure 1. The flowsheet of material balance 

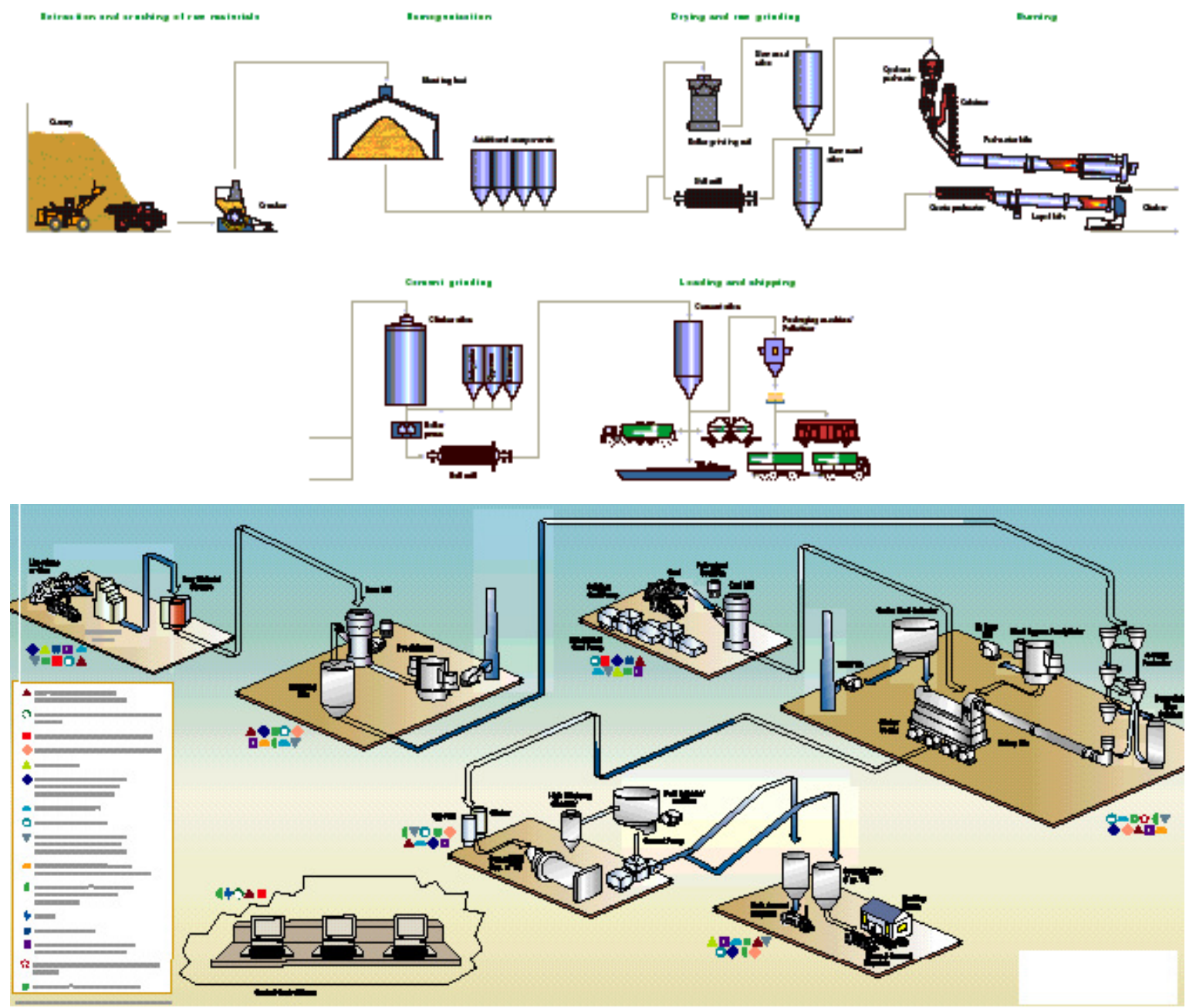

Figure 5.Application of the control system to the cement technological flow 